\title{
Operationalising Municipal Solid Waste Management
}

\author{
Peterson Obara Magutu ${ }^{1}$ and Cliff Ouko Onsongo ${ }^{2}$ \\ ${ }^{1}$ University of Nairobi \\ 2Inoorero University \\ Kenya
}

\section{Introduction}

A municipality is an administrative division composed of a defined territory and population (Al-Salem and Lettieri, 2009). While there are many varieties of municipalities, most fall into one of two categories: a single settlement and a land area similar to a township that may contain multiple settlements, or even just part of one, such as a city's municipality. Municipal Solid Waste (MSW) can be defined as solid waste which includes all domestic refuse and non-hazardous wastes such as commercial and institutional wastes, street sweepings and construction debris (Magutu et al., 2010). The major types of MSW are food wastes, paper, plastic, rags, metal and glass, with some hazardous household wastes such as electric light bulbs, batteries, discarded medicines and automotive parts. MSW is thus seen as primarily coming from households but also includes wastes from offices, hotels, shopping complexes/shops, schools, institutions, and from municipal services such as street cleaning and maintenance of recreational areas. In some countries the solid wastes management system also handles human wastes such as night-soil, ashes from incinerators, septic tank sludge and sludge from sewage treatment plants. The complexities and enormity of the challenges become evident when considering other waste types to be managed and these include industrial solid waste, municipal wastewater, industrial wastewater, storm water and hazardous waste.

This chapter will focus on the major ways of managing the Municipal Solid Waste, especially through the proper long-term strategies by looking at the following four key areas: Formulation of the municipal solid waste management strategy; Objectives of municipal solid waste management; Waste management strategies used in municipal solid waste management; and lastly the challenges facing the implementation of sound municipal solid waste management strategies

\section{Municipal solid waste}

Municipal Solid Waste (MSW) can be defined as solid waste which includes all domestic refuse and non-hazardous wastes such as commercial and institutional wastes, street sweepings and construction debris. In some countries the solid wastes management system also handles human wastes such as night-soil, ashes from incinerators, septic tank sludge and sludge from sewage treatment plants. If these wastes manifest hazardous characteristics they should be treated as hazardous wastes (UNEP, 2005). 
Waste management practices differ for developed and developing nations, for urban and rural areas, and for residential and industrial producers. MSW is thus seen as primarily coming from households but also includes wastes from offices, hotels, shopping complexes/shops, schools, institutions, and from municipal services such as street cleaning and maintenance of recreational areas. Residential and commercial types of solid waste include food wastes, paper, cardboard, plastics, textiles, glass, metals, and ashes, special wastes like bulky items, consumer electronics, batteries, oil, tires and household hazardous wastes. Institutions types of solid waste include paper, cardboard, plastics, wood, food wastes, glass, metals, special wastes, hazardous wastes. Municipal services types of solid waste include Street sweepings, landscape and tree trimmings, general wastes from parks, beaches, and other recreational areas. Therefore, the major types of MSW are food wastes, paper, plastic, rags, metal and glass, with some hazardous household wastes such as electric light bulbs, batteries, discarded medicines and automotive parts (UNEP, 2005; UNEP, 2004).

In recent years the volume of waste has been increasing at an alarming rate, posing a formidable challenge to governments (Magutu et al., 2010). The complexities and enormity of the challenges become evident when considering other waste types to be managed and these include industrial solid waste, municipal wastewater, industrial wastewater, storm water and hazardous waste. Often, different government agencies are mandated to manage different waste sectors. This fragmented approach to waste management, coupled with a lack of clear definition and delineation of the different waste types, makes an assessment of current waste management practices in most countries difficult (UNEP, 2005).

\subsection{Waste management strategies used in municipal solid waste management}

Waste management is the collection, transport, processing, recycling or disposal, and monitoring of waste materials. Operations strategy can be viewed as part of a planning process that coordinates operational goals with those of the larger organization. Since the goals of the larger organization change over time, the operations structure must be designed to anticipate future needs. The operations capabilities of a firm can be viewed as a portfolio best suited to adapt to the changing product and service needs of a firm's customers (Hayes, 1985).

The costs for solid waste management are high especially for collection, transportation, treatment and disposal, which are largely borne by city councils. Methods of collection of waste are either door-to-door or using containers or communal bins. All medium and large cities have administrative structures for providing collection services but often, cities in developing countries use non-compaction trucks for daily collection, with a few cities using compaction trucks and hauling trucks. The most common municipal waste management practices include: recycling/recovery, composting, incineration and land filling/open dumping. The operations strategy is a very important tool in the solid waste management practices and processes (Peters, 1984).

MSW may contain the following materials, which are considered recyclables: ferrous and non-ferrous metals, construction debris, scrap tires, paper/cardboard, plastics, textiles (including cloth and leather), glass, wood/timber, animal bones/feathers, waste oil and grease, cinders/ashes. In the middle-to-low-income cities, there exists a long-standing practice of informal source separation and recycling of materials (Magutu et al., 2010). This has led to the development of enterprises for the gathering, trading and reprocessing of 
materials. For example Mukuru Recycling project which started in 1991 to help men and women scavengers sell recyclable waste to industries. The national ministries support waste recovery and recycling activities at city level although many of these are family businesses. However, since industries would only be interested to use recycled materials when they cost less than the virgin materials, the practice of recycling is so market-driven that recycling has become selective. The disposal of those unselected recyclables remains a problem.

Informal waste separation or waste picking takes place in three ways: At source - this is in large urban areas, e.g., commercial areas or residential areas with apartments/high-rise buildings for high income earners. Here waste pickers sort out the waste before the authorized collection vehicle arrives. During collection, when the collectors segregate recyclable materials during loading and store them inside the truck or on the sides of the vehicles. At the disposal site - where the waste pickers often live on or near the dumps. However, they risk the danger of potential slides and fires. While waste picking means survival for waste pickers the methods of uncontrolled waste picking can reduce the efficiency of the formal collection system and can be detrimental to health due to exposure to biological pathogens.

Composting is not well practiced. Waste materials that are organic in nature, such as plant material, food scraps, and paper products, can be recycled using biological composting and digestion processes to decompose the organic matter (Al-Salem and Lettieri, 2009). The resulting organic material is then recycled as mulch or compost for agricultural or landscaping purposesHousehold organic wastes, including wastes from the restaurants, are often collected for animal feed. But these are either not working or are not operating at full capacity for a number of reasons, such as: High operating and maintenance costs, poor maintenance and operation of facilities, Incomplete separation of non-compostables, such as, plastics and glass, high cost of compost compared to commercial fertilizers.

Another waste treatment method that is practiced is incineration where 90 percent of nonrecyclable municipal solid waste is incinerated. Final disposal of waste is at landfills where 10 percent of non-recyclable municipal solid waste is deposited (Al-Salem and Lettieri, 2009). Singapore has four government-owned and operated incinerators for the disposal of solid waste that is not recycled. However, controversy remains over the soundness of incineration as a waste treatment technology because of greenhouse gas emissions from incinerators. Incineration has been completely banned under the new law on solid waste management (Rio de Janeiro, 1992). The practice of informal incineration or open burning is, however, still prevalent, not only in the rural areas where waste collection is rare but also in peri-urban and urban areas.

The popular meaning of 'recycling' in most developed countries refers to the widespread collection and reuse of everyday waste materials such as empty beverage containers. These are collected and sorted into common types so that the raw materials from which the items are made can be reprocessed into new products. Material for recycling may be collected separately from general waste using dedicated bins and collection vehicles, or sorted directly from mixed waste streams.

Landfills are generally the cheapest and most common disposal method for municipal solid waste (Al-Salem and Lettieri, 2009). Disposing of waste in a landfill involves burying the waste, and this remains a common practice in most countries. Landfills were often established in abandoned or unused quarries, mining voids or borrow pits. A properly designed and well-managed landfill can be a hygienic and relatively inexpensive method of disposing of waste materials. Older, poorly designed or poorly managed landfills can create 
a number of adverse environmental impacts such as wind-blown litter, attraction of vermin, and generation of liquid leachate. An exception is a large city like Singapore, which faces rising disposal costs due to exhaustion of traditional disposal sites, stricter environmental controls and greater waste quantities, thus requiring other methods like incineration to reduce the volume of waste for final disposal. In the other developing countries, open dumping is the common practice, i.e., municipal solid waste is dumped on swamplands and low-lying areas, which are eventually reclaimed for development. The problems associated with landfills, even with those that are clay-lined, include high water table, groundwater contamination and gas migration.

Incineration is a disposal method in which solid organic wastes are subjected to combustion so as to convert them into residue and gaseous products. This method is useful for disposal of residue of both solid waste management and solid residue from waste water management (Al-Salem and Lettieri, 2009). This process reduces the volumes of solid waste to 20 to 30 percent of the original volume. Incineration and other high temperature waste treatment systems are sometimes described as "thermal treatment". Incinerators convert waste materials into heat, gas, steam and ash. Incineration is common in countries such as Japan where land is more scarce, as these facilities generally do not require as much area as landfills. Waste-to-energy (WtE) or energy-from-waste (EfW) are broad terms for facilities that burn waste in a furnace or boiler to generate heat, steam and/or electricity.

\subsection{Formulation of the municipal solid waste management operations strategy}

Operations strategy is the "HOW" in any corporate and market strategy. Operations strategy is no longer a tool for continuous improvement and sustainable competitive advantage in the manufacturing sector only, since it can be now applied in the service industry and public organizations.

The operation strategies used in solid waste management can be modeled using a process chart as follows:

From the model, the formulation of organizational strategy must be done by the CEO and the employees through selected committees. The formulation of organizational strategy should be followed by setting of Annual Objectives in Solid Waste Management. The annual objectives includes to: improve public health of the people; improve the environment; and maintain public cleanliness in order to keep public places aesthetically acceptable; by ensuring the proper storage, collection, transportation, safe treatment and disposal of solid waste. This driven by the annual departmental objectives designed according to the department of environment's major mandates. They are derived from annual departmental objectives especially by the departmental heads and the employees. This is operational Level (origination of Annual Objectives in Solid Waste Management). The policies adequately support the institutions strategic plan: the departmental organizational structure support implementation of strategy; and the procedures/regulations followed by the departments are supportive of change implementation. This should be documented in the current strategic plan (Magutu et al., 2010).

There are so many factors that can enable an organization to take a fresh look at its operations Strategy. The different factors that impact on the operations strategy are: most managers felt that the emergence of aggressive and highly competent competitors, demanding and environmentally conscious customers. Other secondary factors include: advances in production and information technology, global business operations, business process re-engineering techniques and the enormous opportunities for operational 
Formulation of Organizational Strategy

(CEO and the employees through selected committees)

\section{Solid Waste Management Operations Strategy Development Process}

Variables very important in the process of defining the best solid waste management strategies:

The external environment of the Municipality

Drivers/creation of a Fresh Look at Operations StrategyThere are so many factors that can enable an organization to take a fresh look at its operations Strategy: the emergence of aggressive and highly competent competitors, demanding and environmentally conscious customers. Other secondary factors include: advances in production and information technology, global business operations,

business process re-engineering techniques and the enormous opportunities for operational

\section{efficiencies and economies}

The policies should adequately support the institutions strategic plan: the departmental organizational structure support implementation of strategy; and the procedures/regulations followed by the departments are supportive of change implementation. This should be documented in the current strategic plan
The annual departmental objectives need to be designed according to the department of environment's major mandates. They are derived from annual departmental objectives especially by the departmental heads and the employees. This is operational Level.

Manage the Challenges Facing CC in the Operations Strategy Implementation With Respect to Solid Waste Management

The factors considered to have a strongly effect on the CC's operations strategy implementation with respect

to solid waste management: Inability to formulate and implement sound solid waste management policies,

Inadequate treatment and disposal of solid waste; Inadequate landfill disposal, Poor formulation and

enforcement of laws and regulations relating to solid waste management; Poor services for solid waste collection and Limited utilization of recycling activities; the Inability to regulate and monitor the activities of all generators of solid waste, and Poor transportation services provision.

Secondary challenges include: The deficient accounting systems ; Dumping along the back lanes and street corners within the city and its suburbs; High risk of environmental pollution; Inadequate service coverage and operational inefficiencies of service; Large amounts of uncollected solid waste; Lack of adequate and appropriate staff; Inadequate management of hazardous and healthcare waste; No controls from the management side to prevent toxic and even hazardous waste; Very inadequate billing system

Fig. 1. Formulation of Strategies Used In Municipal Solid Waste Management 
efficiencies and economies. The external environment of the municipality's trends in the market; changes in customer wants and expectations (demanding speed of delivery, high quality, and low price); Identifying the company's strengths, special skills of workers, such as expertise in providing customized services or knowledge of information technology; the trends in the political environment changes in the political climate-local, national, and international) and forming partnerships with international firms(Magutu et al., 2010).

Investment on scanning the environment of operation before developing the solid waste management operations strategy is important. As one invests on time and effort in implementing its operations strategy after the environmental scanning and formulation of operations strategy, there is need to invest in its implementation. There are a number of challenges which needs to be managed during the implementation of operations strategy with respect to solid waste management. The factors considered to have a strongly effect on the municipal solid waste strategy implementation include: Inability to formulate and implement sound solid waste management policies, Inadequate treatment and disposal of solid waste; Inadequate landfill disposal, Poor formulation and enforcement of laws and regulations relating to solid waste management; Poor services for solid waste collection and Limited utilization of recycling activities; the Inability to regulate and monitor the activities of all generators of solid waste, and Poor transportation services provision. The secondary challenges include: The deficient accounting systems ; Dumping along the back lanes and street corners within the city and its suburbs; High risk of environmental pollution; Inadequate service coverage and operational inefficiencies of service; Large amounts of uncollected solid waste; Lack of adequate and appropriate staff ; Inadequate management of hazardous and healthcare waste; No controls from the management side to prevent toxic and even hazardous waste; Very inadequate billing systems (Magutu et al., 2010).

This proper management of the challenges finally leads to proper solid waste management.

\section{Success stories in solid waste management}

Rapid urbanization and the associated growth of industries and services is an essential feature of economic and demographic development in most developing countries. Cities are currently absorbing two-thirds of the total population increase throughout the developing world (UNCHS, 1993). Another striking growth is the steady growth in size of cities. One of the most important environmental consequences of urbanization is the amount of solid waste that is generated. These wastes have fast outstripped the ability of natural environment to assimilate them and municipal authorities to dispose of them in a safe and efficient manner. The resulting contamination affects all environmental media and has a direct negative effect on human health and the quality of urban life.

Most governments all over the world where waste management services have successfully been done subsidizes the budgets for solid waste management up-to over 60 percent. In Japan for example before privatization of solid waste management services, government subsidy to SWM used to be 80 percent while in Sweden it is 70 percent despite residents still paying an equivalent of kshs 800 per month for the solid waste management services. Accra in Ghana, residents pay up to Kshs 700 per month for the solid waste management services. Singapore has a collection rate of more than 90 percent while in Bangkok, Jakarta and Kuala Lumpur the rate is more than 80 percent. In Indonesia, collection rates have been improved through a pre-collection system at villages, which deposit their municipal solid waste at transfer or temporary storage facilities (Rio de Janeiro, 1992). 
In Dar es Salaam in Tanzania, the government made a bold step in 1994 to privatize the waste collection and transportation aspects where the city was zoned and different private companies were given areas of operation while collecting waste management charges approved by the various municipalities. Different municipalities enacted their own by-laws to govern and guide the operations of the private sector. The City only manages the disposal site but this again, the city of Dar-es-salaam has partnered with a strategic investor from Germany to develop a sanitary landfill site as for a long time the city has operated with a controlled disposal site. The private companies collect waste management charges from the citizens and only approved rates by the council are applied. The city has a department for solid waste disposal, which only develops policies, rules governing the private sector operation, supervision and the management of the disposal site. The private companies contracted are locals and sometimes they get a back- up from the city council whenever they cannot deliver. In this case, the council has to have what to fall back to and therefore the council cannot afford at any time to have no fleet of vehicles (Rio de Janeiro, 1992).

In Cairo Egypt, the Government decided to invite international bidders for the solid waste management services when the council failed to provide the required services and the city was dirty while the residents were not agreeable to pay for services, which were hardly there in 2002. The Giza region in Cairo, which has a population of 6.5 million was divided into three zones and contracted to three different companies. Jacorossi Impresse is one of the companies managing cleansing services from a population of about 1.2 million under a $15 \mathrm{yr}$ period contract (Rio de Janeiro, 1992).

\section{Conclusion}

Solid waste management or municipal solid waste management varies widely among different countries and regions. Most of the management services are often provided by local government authorities, or by private companies in the industry. This can be done through The application of waste hierarchy which refers to the "3 Rs" reduce, reuse and recycle. This hierarchy classifies waste management strategies according to their desirability in terms of waste minimization aimed at extracting the maximum practical benefits from products and to generate the minimum amount of waste. The Extended Producer Responsibility (EPR) is a strategy designed to promote the integration of all costs associated with products throughout their life cycle including end-of-life disposal costs into the market price of the product. The other strategy is Polluter Pays Principle, where the polluting party pays for the impact caused to the environment, which implies that a waste generator pays for appropriate disposal of the waste.

\section{References}

Al-Salem S.M. and Lettieri P., (2009), "Life Cycle Assessment (LCA) of Municipal Solid Waste Management in the State of Kuwait" European Journal of Scientific Research, ISSN 1450-216X Vol.34 No.3 (2009), pp.395-405

Hayes RH. 1985. Strategic Planning: Forward In Reverse? Harvard Business Review 63(6): 67-77.

Magutu O.P, Mbeche M.I, Nyamwange O.S, Mwove M. \& Ndubai E.R., 2010, “Formulation and Implementation of Operation Strategies Used in Solid Waste Management: Case Study of City Council of Nairobi" IBIMA Publishing Vol. 2010 (2010), 842702, 
Journal of African Research in Business \& Technology, 21 pages: available on-line at www.ibimapublishing.com/journals/JARBT/2010/842702/842702.pdf

Peters, T. J. , 1984, In Search of Excellence: Lessons from America's Best Run Companies. New York: Warner Books.

Rio de Janeiro, 1992, "Environmentally Sound Management of Solid Wastes and Sewagerelated Issues" in the United Nations Conference on Environment and Development, Chapter 21.3 of Agenda 21

UNEP (2004) The Use of Economic Instruments in Environmental Policy: Opportunities and Challenges, UNEP, Geneva.

UNEP (2005) Selection, Design and Implementation of Economic Instruments in the Solid Waste Management Sector in Kenya: The Case of Plastic Bags, UNEP-ETB, Geneva. IN “ United Nations Conference of Environment and Development, 1992 - Agenda 21" 


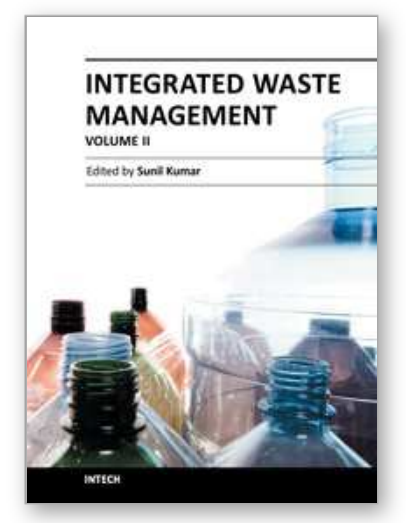

\author{
Integrated Waste Management - Volume II \\ Edited by Mr. Sunil Kumar
}

ISBN 978-953-307-447-4

Hard cover, 472 pages

Publisher InTech

Published online 23, August, 2011

Published in print edition August, 2011

This book reports mostly on institutional arrangements under policy and legal issues, composting and vermicomposting of solid waste under processing aspects, electrical and electronic waste under industrial waste category, application of GIS and LCA in waste management, and there are also several research papers relating to $\mathrm{GHG}$ emission from dumpsites.

\title{
How to reference
}

In order to correctly reference this scholarly work, feel free to copy and paste the following:

Peterson Obara Magutu and Cliff Ouko Onsongo (2011). Operationalising Municipal Solid Waste Management, Integrated Waste Management - Volume II, Mr. Sunil Kumar (Ed.), ISBN: 978-953-307-447-4, InTech, Available from: http://www.intechopen.com/books/integrated-waste-management-volumeii/operationalising-municipal-solid-waste-management

\section{INTECH}

open science | open minds

\author{
InTech Europe \\ University Campus STeP Ri \\ Slavka Krautzeka 83/A \\ 51000 Rijeka, Croatia \\ Phone: +385 (51) 770447 \\ Fax: +385 (51) 686166 \\ www.intechopen.com
}

\author{
InTech China \\ Unit 405, Office Block, Hotel Equatorial Shanghai \\ No.65, Yan An Road (West), Shanghai, 200040, China \\ 中国上海市延安西路65号上海国际贵都大饭店办公楼 405 单元 \\ Phone: +86-21-62489820 \\ Fax: +86-21-62489821
}


(C) 2011 The Author(s). Licensee IntechOpen. This chapter is distributed under the terms of the Creative Commons Attribution-NonCommercialShareAlike-3.0 License, which permits use, distribution and reproduction for non-commercial purposes, provided the original is properly cited and derivative works building on this content are distributed under the same license. 